\title{
Leydig cell tumor in a boy with undiagnosed precocious puberty due to congenital adrenal hyperplasia
}

\author{
Dong Trieu Phuong Tran ${ }^{*}$, Tan Thi Minh Nguyen ${ }^{1}$, Thuy Thi Diem Hoang ${ }^{1,2}$ \\ From 8th APPES Biennial Scientific Meeting \\ Darwin, Australia. 29 October - 1 November 2014
}

\section{Aims}

To describe the clinical presentation and sequelae of undiagnosed congenital adrenal hyperplasia (CAH).

\section{Methods}

Case report.

\section{Results}

A 5-year-old boy presented with penis and testicular enlargement for 1 year. The past medical history had no severe vomiting or failure to thrive. His height was $120 \mathrm{~cm}$ (> 95th percentile). His penis was $7 \mathrm{~cm}$ and asymmetric testicles. Scrotal ultrasound detected his left testicle was $1.5 \times 0.9 \mathrm{~cm}$ and his right testicle was $3.0 \times$ $2.0 \mathrm{~cm}$ with a heterogeneous hypoechoic mass $1.8 \times 2.0$ $\mathrm{cm}$ at inferior pole with sheath thickness, clearly margin. His bone age was 14 years. His serum 17-hydroxypregnenolone and testosterone levels were elevated to $1768 \mathrm{ng} / \mathrm{dl}$ and $694.5 \mathrm{ng} / \mathrm{dl}$, respectively. His serum hCG was below $1.2 \mathrm{IU} / \mathrm{L}$ and DHEA-S $<0.001 \mathrm{mcg} / \mathrm{ml}$. An absent $\mathrm{LH}$ response after GnRH stimulation was recorded. He was diagnosed with $\mathrm{CAH}$ and treated with hydrocortisone. After one month of treatment, his serum 17-hydroxypregnenolone and testosterone levels decreased to $11 \mathrm{ng} / \mathrm{dl}$ and $20.75 \mathrm{ng} / \mathrm{dl}$, respectively. Then, he underwent an open testis biopsy for further evaluating of the mass of his right testicle. Histological examination of the testicle demonstrated large, polygonal, and eosinophilic cells with round nuclei and prominent nucleoli, which are consistent findings with Leydig cell tumors. Thereafter, the child underwent radical orchiectomy of his right testicle.

'Department of Nephrology and Endocrinology, Children's Hospital 2,

HoChiMinh City, Vietnam

Full list of author information is available at the end of the article

\section{Conclusion}

Undiagnosed congenital adrenal hyperplasia can affect normal development. Universal newborn screening is recommended for congenital adrenal hyperplasia.

Written informed consent was obtained from the patient for publication of this abstract and any accompanying images. A copy of the written consent is available for review by the Editor of this journal.

\section{Authors' details}

'Department of Nephrology and Endocrinology, Children's Hospital 2, HoChiMinh City, Vietnam. 'Department of Pediatrics, Faculty of Medicine, Pham Ngoc Thach University of Medicine, HoChiMinh City, Vietnam.

Published: 28 April 2015

doi:10.1186/1687-9856-2015-S1-P46

Cite this article as: Tran et al:: Leydig cell tumor in a boy with undiagnosed precocious puberty due to congenital adrenal hyperplasia. International Journal of Pediatric Endocrinology 2015 2015(Suppl 1):P46.

Submit your next manuscript to BioMed Central and take full advantage of:

- Convenient online submission

- Thorough peer review

- No space constraints or color figure charges

- Immediate publication on acceptance

- Inclusion in PubMed, CAS, Scopus and Google Scholar

- Research which is freely available for redistribution

Submit your manuscript at www.biomedcentral.com/submit 